\title{
STABILIZUJĄCA ROLA USTROJU MONARCHICZNEGO W ŚWIECIE ARABSKIM NA PRZYKLADZIE ROZWOJU HASZYMIDZKIEGO KRÓLESTWA JORDANII
}

\begin{abstract}
W ciągu ostatnich dwudziestu lat obserwujemy proces narastającego kryzysu politycznego w świecie arabskim. Rok 2011 wbrew nadziejom zachodnich obserwatorów nie przyniósł zmian na lepsze. W przypadku Syrii, Iraku czy Jemenu mamy do czynienia $\mathrm{z}$ wybuchem długotrwałych wojen domowych. Warto zwrócić uwagę na fakt, że rozpad struktur państwa dotyczy wyłącznie republik arabskich, natomiast kraje o ustroju monarchicznym zachowują stabilność i cechuje je mniejsza represyjność aparatu władzy wobec obywateli. Tekst powyższy zwraca uwagę na rolę czynnika, jakim jest legitymizacja władzy. W republikach brak jest realnego elementu suwerenności narodu. Legitymizacja władzy opiera się głównie na posiadaniu siły wojskowej. W monarchiach zachowano tradycyjną legitymizację opartą na idei delegowania władzy przez Boga. Ta koncepcja okazała się dość skuteczna w segmentarnych społeczeństwach arabskich.

W drugiej części tekstu tezy te udowadniane są na podstawie wydarzeń z historii Haszymidzkiego Królestwa Jordanii. Zwrócono uwagę jak ważna była rola Haszymidów w utworzeniu tego państwa. Wskazano na liczne kryzysy wewnętrzne z lat 1948-1949, 1956-1957, 1967-1970 i 1989-1991, które państwo przetrwało w dużej mierze dzięki autorytetowi monarchii. On też pozwalał uniknąć anarchizacji państwa a równocześnie trwałej opresyjnej dyktatury. W środowisku pozbawionym wyraźnej identyfikacji narodowej (na poziomie państwa) monarchia okazała się głównym elementem stabilizującym.

Słowa kluczowe: monarchia, naród, Haszymidzi, Jordania, Husajn, Palestyńczycy.
\end{abstract}

Wydarzenia rozgrywające się $\mathrm{w}$ ciągu ostatnich kilkunastu lat $\mathrm{w}$ świecie arabskim przykuwają uwagę zachodniej opinii publicznej. Wydaje się jednak, że dramatycznym opisom rzadko towarzyszy głębsza analiza zjawisk. Wiele komentarzy razi wręcz płytkością wniosków. Sytuacja jest jednak poważna i już na obecnym etapie uprawnia do podjęcia przynajmniej wstępnej analizy. Wnioski mogą być różne, ale powtarzanie pewnych dogmatów politycznych nie prowadzi do konstruktywnych rezultatów.

W świecie arabskim narasta anarchia polityczna. W krajach, gdzie udaje się jej uniknąc na ogół powstają represyjne dyktatury, ale i one nie gwarantują trwałego porządku. W wielu krajach arabskich zamęt polityczny przybrał charakter regularnych wojen domowych. Dotyczy to Syrii, Iraku, Libii, Sudanu i Jemenu. Obszar Syrii i Iraku to

\footnotetext{
${ }^{1}$ Dr hab. Bartosz Wróblewski prof. UR, Uniwersytet Rzeszowski, Instytut Nauk o Polityce, ul. mjr. W. Kopisto 2A, 35-959 Rzeszów e-mail: bwrob@o2.pl
} 
obecnie największa geopolityczna przestrzeń ogarnięta wojną wewnętrzną. Co ważniejsze sytuacja ta nie ma charakteru przypadkowego. Po 2001 r. anarchizacja stopniowo narasta a wydarzenia tzw. „Arabskiej Wiosny” wyraźnie ją przyspieszyły. W przypadku Iraku rozpad państwa wynika z najazdu wojsk USA i ich polityki po 2003 r., z kolei zamęt w Syrii i Jemenie spowodowany został przyczynami wewnętrznymi. Tak więc mamy do czynienia z narastającym rozpadem pewnego porządku politycznego na dużym obszarze. Interwencje sił zachodnich nie tylko nie stabilizują sytuacji, ale przeciwnie wyraźnie powiększają ogólne zamieszanie.

Nawet na obecnym etapie wydarzeń można dostrzec pewną prawidłowość. O ile republiki arabskie ogarnia zamęt polityczny lub stają się represyjnymi dyktaturami to monarchie zachowują zdumiewającą stabilność wewnętrzną. Co więcej, osiągają to stosując mniej represji policyjnych niż reżimy republikańskie. Ta różnica wprost rzuca się w oczy. Jakaś próba odpowiedzi na pytanie o przyczyny tego zjawiska wydaje się potrzebna.

W komentarzach, w których w ogóle zauważa się to zjawisko wskazywana jest czasem jedna przyczyna. Stabilność monarchii arabskich ma wynikać z faktu posiadania przez nie bogactw naftowych. Pozwalają one władzom kupować sobie poparcie polityczne i inwestować $\mathrm{w}$ infrastrukturę. $\mathrm{Z}$ poglądem takim nie można się zgodzić. Owszem petrodolary pozwalają niektórym monarchiom arabskim stabilizować swą sytuację wewnętrzną, ale przynajmniej dwie z nich Maroko i Jordania nie posiadają tych bogactw. Poza tym takie republiki jak Irak, Libia i Algieria posiadają olbrzymie złoża ropy naftowej co nie uchroniło ich od wstrząsów wewnętrznych. Tak więc ta prosta odpowiedź wydaje się nietrafna i chyba wynika $z$ koncentracji uwagi na jednym tylko przykładzie Królestwa Arabii Saudyjskiej.

W poniższym tekście pada nieco inne wyjaśnienie tego fenomenu. Wskazany zostanie fakt istnienia legalizmu monarchicznego, ideologii władzy, która sprawia, że królestwa arabskie nie muszą polegać wyłącznie na sile jako zabezpieczeniu władzy elit. W tym kontekście szczególnie istotny będzie przykład Haszymidzkiego Królestwa Jordanii. Stabilność tego państwa jest faktem wręcz zadziwiającym. Wszystkie obiektywne czynniki, takie jak brak surowców, marne gleby, i masy uchodźców obciążających gospodarkę powinny prowadzić do kompletnej destabilizacji tego państwa, tymczasem jest ono zdumiewająco spokojne i trwałe. I tylko jeden element odróżnia je od sąsiadów, a jest nim ustrój monarchiczny ${ }^{2}$.

\section{ZAGADNIENIE USTROJU}

W rozważaniach nad fenomenem upadku republik i stabilnością monarchii w świecie arabskim jeden fakt przeszkadza Europejczykom i Amerykanom w obiektywnej analizie. Chodzi o to, że ewolucja polityczna w świecie arabskim w ciągu ostatnich 60 lat zaprzecza wyraźnie podstawowym dogmatom przyjmowanym w świecie zachodnim jeśli chodzi o ewolucję społeczeństw. W wyobrażeniach Zachodu idea suwerenności narodu, rozumianego jako społeczeństwo obywatelskie, jest w sposób oczywisty wyższa od koncepcji suwerenności władcy. Nie chodzi tu nawet o to, czy państwo jest monarchią czy

\footnotetext{
${ }^{2}$ A. George, Jordan. Living in the Crossfire, Zed Books, London and New York 2005, s. XI-XII.
} 
republiką, lecz o to, czy społeczeństwo jest suwerenem uprawnionym do zmiany prawa i wybierania rządów ${ }^{3}$.

W Europie monarchie dawno pogodziły się $\mathrm{z}$ ideą suwerenności narodu, w republikach jest to oczywistość i podstawowa zasada polityczna. To samo dotyczy wszystkich państw wzorujących swe ustroje na Europie (czyli przytłaczającej większości). Tymczasem w monarchiach arabskich zasada ta nie obowiązuje. Monarchie te pozostały przy odwiecznej zasadzie, że suwerenem jest władca i szerzej ród panujący a suwerenność tą otrzymał on $\mathrm{z}$ nadania Boga. Ludność państwa pozostaje poddanymi i nie istnieje zasada, która pozwalałby jej legalnie zlikwidować monarchie. To nie oznacza, że monarchie te nie mogą akceptować parlamentaryzmu czy wolności wypowiedzi. Przeciwnie, w Jordanii, Maroku czy Kuwejcie istnieje dość znaczna jak na region swoboda wypowiedzi oraz rozwinięta instytucja parlamentu. Mimo to król pozostaje instytucją nadrzędną i może w sytuacji nagłej cały ten system swobód zawiesić. Co więcej, można przyjąć, że istnieje on jako szerokie spektrum przywilejów nadanych przez monarchię poddanym. Nie oznacza jednak suwerenności narodu ${ }^{4}$.

Dla obserwatora zachodniego taki typ ustroju jest znany. Może go porównywać do monarchii europejskich z końca XVIII w. i początku XIX w. Wielu próbowało przedstawić świat arabski właśnie według takiego schematu jako obszar zacofany ustrojowo, który jednak podąża tą samą ścieżką co świat Zachodu. Zgodnie z tym uogólnieniem wraz z rozwojem społeczno-gospodarczym regionu idea suwerenności narodu jako naturalnie wyższa będzie musiała wyprzeć monarchiczną ideę czyniącą z władcy główny zwornik państwa. W wielu wypadkach musiało to oznaczać obalenie monarchii i powstanie republik. W latach 1950-1970 rzeczywiście upadły monarchie w Egipcie, Iraku, Jemenie i Libii. Przetrwały one głównie na konserwatywnym społecznie Półwyspie Arabskim. Wszystko to zdawało się potwierdzać schemat. Zgodnie z tym przewidywaniem również tam, gdzie władza królestwa przetrwa będzie musiała zaakceptować parlamentaryzm i suwerenność społeczeństwa ${ }^{5}$.

Dziś można wskazać, że przewidywania te były błędne. Przede wszystkim okazało się, że w świecie arabskim republiki nie stały się bardziej postępową formą ustroju. Powstawały na ogół na wskutek wojskowych zamachów stanu. Co gorsza miały powszechną tendencję do przekształcania się w opresyjne i długotrwałe oligarchie oficersko-urzędnicze. Rozwój społeczny był w nich blokowany bardziej niż w monarchiach. Przywódcy republik mieli też niebezpieczną tendencję do awanturniczej polityki zagranicznej. Urzędy prezydenckie oznaczały władzę dożywotnią. Generalnie ustroje te ulegały degeneracji a władza w nich opierała się na zastosowaniu przemocy. Czasem wykształcały się w takich dyktaturach de facto rody panujące, a w Syrii doszło nawet do dziedziczenia władzy ${ }^{6}$.

Drugi element tych przewidywań czyli zmiany w królestwach arabskich także nie miał miejsca. Wiele $\mathrm{z}$ nich pozostało absolutnymi monarchiami bez żadnych instytucji parlamentarnych. Monarchie $\mathrm{z}$ nad Zatoki Perskiej łączą to $\mathrm{z}$ doskonałym rozwojem

\footnotetext{
${ }^{3}$ M. Król, Historia myśli politycznej od Machiavellego po czasy wspótczesne, Gdańsk 2001, s. 215 216.

${ }^{4}$ J. Zdanowski, Historia Bliskiego Wschodu w XX wieku, Wrocław 2010, s. 469-472 i 549.

${ }^{5}$ A. Hourani, Historia Arabów, Gdańsk 2002, s. 401-406.

${ }^{6}$ J. Żebrowski, Dzieje Syrii od czasów najdawniejszych do wspótczesności, Warszawa 2006, s. 189;

J. Danecki, Arabowie, Warszawa 2001, s. 378-379.
} 
gospodarczym i wzrostem zamożności miejscowych społeczeństw. Inne monarchie np. Maroko mają parlament i nie najgorzej rozwiniętą sieć społecznych organizacji. Jednak rozwój organizacji obywatelskich wcale nie zmienił faktu, że to król pozostaje niekwestionowanym suwerenem.

\section{IDEA NARODU}

Jeszcze raz trzeba podkreślić fundamentalną różnicę jaka zachodzi między ustrojami zachodnimi, w tym również monarchiami, a sytuacją świata arabskiego. Idea suwerenności narodu stała się na Zachodzie aksjomatem. Naród utożsamiany ze wspólnotą obywateli państwa ma nie tylko prawo w drodze wyborów zmieniać aktualną ekipe rządzącą, ale przede wszystkim przekształcać ustawodawstwo. Gdy państwo jest monarchią to wola narodu może ją legalnie obalić. Co więcej, wola większości może uchwalić prawa, które np. będą dyskryminować jakąś grupę obywateli, czy łamać powszechnie dotąd szanowane zwyczaje. Żadne prawa nie są absolutne i niezależne od woli większości. Co prawa na Zachodzie od dłuższego czasu panuje konsensus liberalny $\mathrm{i}$ tendencja do tolerancji. Mimo to warto pamiętać, że wynika to $\mathrm{z}$ przyzwyczajenia wyborców. Zasadą suwerenności narodu jest jednak przyznanie wspólnocie narodowej (jej większości) możliwości dowolnego zmieniania prawa ${ }^{7}$.

Aby taki ustrój mógł w ogóle zaistnieć musiał najpierw powstać specyficzny rodzaj społeczeństwa. Naród typowy dla Europy i Ameryki Północnej stanowi fenomen lokalny. Taka społeczność wytworzyła ścisły emocjonalny związek z państwem. Jednocześnie w Europie całkowitemu rozkładowi uległy wspólnoty plemienne, również rody przestały de facto istnieć. Drobne etnosy, albo zintegrowały się z narodami państwowymi, albo same przyjęły narodowy typ świadomości. Równocześnie na Zachodzie zanikła polityczna solidarność w ramach wielkich grup religijnych. Wyznanie stało się generalnie sprawą indywidualną i rzadko wpływa na postrzeganie prawa publicznego. Przede wszystkim takie wspólnoty jak katolicy, luteranie czy kalwini poza marginalnymi wyjątkami, nie odczuwają imperatywu solidarnych działań politycznych ponad granicami państw. Przeciwnie, w ciągu ostatnich 200 lat wielokrotnie ludzie różnych wyznań okazywali gotowość do walki ze współwyznawcami z sąsiedniego państwa. Jest to wyraźny dowód, że w europejskiej kulturze wspólnota wyobrażona narodu wyparła skutecznie podobną koncepcję solidarności współwyznawców. Tak więc idea narodu jako wspólnoty politycznej nie ma na Zachodzie żadnego równorzędnego konkurenta ani wśród wspólnot lokalnych, ani na szczeblu ponadpaństwowym ${ }^{8}$.

Ten sam termin stosowany wobec społeczeństw azjatyckich czy afrykańskich może tracić podstawowy sens. W świecie arabskim wspólnoty narodowe do początku XX w. nie powstały. W krajach islamu utrzymały się silne związki rodowe oraz plemiona. Co ważniejsze podstawą identyfikacji zbiorowej pozostała przynależność wyznaniowa. Wspólnota muzułmańska, czyli umma stanowi najistotniejszy byt polityczny ponad grupami plemiennymi. W świetle teorii prawnych islamu przynależność do ummy zobowiązuje członków do solidarności politycznej a nawet wojskowej. Solidarność ma dotyczyć zwłaszcza szerzenia islamu. Ponieważ islam jest podzielony na grupy wyznaniowe skonfliktowane ze sobą więc de facto wspólnotami politycznymi są odłamy

\footnotetext{
${ }^{7}$ A. Sylwestrzak, Historia doktryn politycznych i prawnych, Warszawa 2006, s. 213-218.

${ }^{8}$ M. Król, Historia ..., s. 106-107 i 115-117.
} 
tej religii takie jak szyici, sunnici czy druzowie. Dla tych grup granice współczesnych państw są najmniej istotne?

W świecie arabskim i szerzej w cywilizacji islamu europejskie pojęcie narodu państwowego było nie znane aż do okresu gdy gwałtownie wzrosły tam wpływy zachodnie. W istocie dopiero od końca XIX w. nastąpiła recepcja wielu europejskich idei politycznych w tym także koncepcji narodu. W świecie arabskim przyjęto tą ideę w formie panarabizmu. Inteligencja arabska za wspólnotę narodową uznała wszystkich użytkowników literackiego języka arabskiego. Ta jedność kulturowa rzeczywiście istnieje i obejmuje obszar od Maroka do Iraku. Problem polega na tym, że jedność językowa nigdy nie stała się wspólnotą polityczną. Idea panarabska zyskała popularność wśród inteligencji arabskiej, ale nie wytworzyła rzeczywistej jedności działań politycznych i co istotniejsze nie usunęła $z$ wyobraźni zbiorowej koncepcji jedności wspólnot religijnych oraz solidarności plemiennej i rodowej. To wszystko miało bardzo poważne konsekwencje dla prób wprowadzania w świecie arabskim idei suwerenności narodu i ustroju republikańskiego ${ }^{10}$.

W krajach arabskich, w których ustanowiono republiki powinna obowiązywać zasada suwerenności narodu. Jednak elity za naród uznawały ogół Arabów czyli byt istniejący jedynie w jej planach. Suwerenem natomiast nie były konkretne społeczeństwa krajów arabskich. Zresztą obiektywnie trzeba dodać, że były to na ogół państwa powołane do życia przez mocarstwa europejskie, często dopiero po I wojnie światowej. Państwa te miały sztuczne granice i społeczeństwa podzielone na grupy wyznaniowe lub plemienne. Tak więc idea suwerenności narodu była trudna do realnego zastosowania bo nie istniały narody, których powstanie w Europie poprzedzało zwycięstwo zasady wszechwładzy wspólnoty obywatelskiej. Realne stosowanie tej idei mogło doprowadzić do rozbicia państwa. Na ogół zresztą $\mathrm{w}$ republikach arabskich faktyczny parlamentaryzm istniał krótko lub w ogóle nie był stosowany. Elity cywilne były zastępowane przez hunty oficerskie, które zdobywały władzę w wyniku zamachu stanu. Rządy wojskowych głosiły panarabizm, często też tzw. socjalizm arabski. Na ogół utrwalały się na długie dziesięciolecia. Podstawową metodą utrzymania władzy stawało się stosowanie siły. Siła $\mathrm{z}$ kolei rzadko łączyła się z autorytetem wyższego rzędu ${ }^{11}$.

\section{MONARCHIE ARABSKIE}

Te wyjaśnienia pomogą zrozumieć odmienność zasad na jakich opierają się królestwa arabskie. W monarchicznych krajach arabskich zasada suwerenności narodu nie jest uznawana. Dotyczy to również królestw Maroka i Jordanii, gdzie od dawna działają parlamenty i odbywają się rywalizacyjne wybory. W monarchiach arabskich suwerenem zawsze jest monarcha i szerzej ród panujący. Ich suwerenna władza pochodzi od Boga i ma być sprawowana zgodnie $\mathrm{z}$ prawem islamskim, co zresztą jest bardzo różnie interpretowane w różnych krajach. Oczywiste jest również, że król pozostaje szefem całej administracji, policji, armii i sił bezpieczeństwa.

Uzasadnienia dla władzy rodów panujących pochodzą nie $\mathrm{z}$ arsenału współczesnych doktryn demokratycznych lecz $\mathrm{z}$ tradycyjnych praw islamu. Jednocześnie trzeba

\footnotetext{
${ }^{9}$ J. Danecki, Arabowie..., s. 378-379 i 384-385.

${ }^{10}$ Ibidem, s. 378-379 i 384-385.

${ }^{11}$ P.J. Vatikiotis, Politics and Military in Jordan: A Study of the Arab Legion 1921-1957, London 1967, s. $1-2$ i 142.
} 
podkreślić, że ten legalizm monarchiczny ma dwa odmienne źródła. Arabskie monarchie można podzielić na dwa zasadnicze typy. Pierwszym są niewielkie emiraty będące w istocie plemiennymi władztwami, które gwałtownie się wzbogaciły w XX w., drugim rozległe królestwa, w których król rządzi wielomilionowym społeczeństwem muzułmańskim. W tym drugim przypadku ród panujący stara się odwołać do religijnego autorytetu.

Niewielkimi państwami plemiennymi są emiraty z nad Zatoki Perskiej. Są to takie monarchie jak Kuwejt, Katar, Bahrajn i każdy z siedmiu emiratów tworzących Zjednoczone Emiraty Arabskie. Podstawą takiego państwa jest plemię, czyli zespół rodów uznających pochodzenie od wspólnego przodka. Na czele tego zespołu stoi jeden z rodów, którego autorytet uznają inne. Teoretycznie wszyscy członkowie plemienia są krewnymi monarchy. Dlatego szokujące przywileje dla pełnoprawnych obywateli niektórych emiratów nie wynikają tylko z gry politycznej. Władca ma obowiązek dbania o tych poddanych jak o swoich krewnych. Natomiast ludzie z poza rodów tworzących plemię są jego obsługą i nie ma powodu by mieli równe prawa. Mogą być zresztą bardzo dobrze opłacani, ale nie należą do plemiennej wspólnoty. W takim ustroju władza rodziny panującej nie wymaga dodatkowych uzasadnień. Została ona zaakceptowana przez plemię, często setki lat temu, gdy były to małe wspólnoty (liczące często ok. 1 tys. ludzi). Jeśli się utrzymała to dlatego, że zapewniała krewnym sukces polityczny i finansowy. Należy też dodać, że te niewielkie emiraty arabskie nigdy nie rościły sobie praw do pełnej i absolutnej suwerenności. W okresie między XVI a XIX w. uznawały na ogół formalne zwierzchnictwo albo państwa osmańskiego, albo Persji. W XX w. podlegały Wielkiej Brytanii. I dopiero dzięki jej protekcji uzyskały w drugiej połowie zeszłego wieku status państw niepodległych ${ }^{12}$.

Można podać dwa przykłady monarchii w Zjednoczonych Emiratach Arabskich, mianowicie Dubaj i Al-Fudżajra. Zgodnie z danymi z 1968 r. w Dubaju było 7864 pełnoprawnych poddanych należących do spokrewnionych rodów (a raczej grup rodowych). Rządzącym buła grupa Banu Jas licząca 3913 ludzi i spośród niej wywodziła się rodzina panująca, która jednak była przede wszystkim naczelnikiem Banu Jas. Z kolei w Al-Fudżajra było wtedy 9138 pełnoprawnych poddanych. Rządząca była tam grupa rodowa Asz-Szarkijjun licząca 8372 osoby. W tym przypadku była to nie tyle grupa rządząca, co większość pierwotnej ludności osady tworzącej emirat. Rodzina rządząca musiała być akceptowana przez członków tej grupy rodowej i przewodziła im na zasadzie autorytetu bo przecież nie posiadała aż do XX w. żadnego aparatu władzy. W tego typu emiratach nie było parlamentów, ale konsultacja decyzji ze współrodowcami była oczywistością. Obecnie ludność tych państewek niepomiernie wzrosła, ale w istocie ich obywatelami pozostały te właśnie dominujące grupy rodowe ${ }^{13}$.

O ile w niewielkich państwach znad Zatoki Perskiej legitymizacja władzy wywodzi się ze zwyczajów i precedensów lokalnych o tyle w rozległych monarchiach arabskich takich jak Maroko, Arabia Saudyjska czy nawet Jordania rządy konkretnego rodu panującego muszą się oprzeć na idei, którą zaakceptuje wielomilionowe społeczeństwo. Monarchie te

\footnotetext{
12 J. Zdanowski, Historia Wschodniej Arabii, Wrocław 2004, s. 332-336.

${ }^{13}$ Ibidem, s. 332-333. Niestety, nie znalazłem nowszych danych na temat podziałów plemiennych w ZEA. Po uzyskaniu niepodległości najprawdopodobniej władze przestały je publikować. Dla porównania Dubaj w 1995 r. miał szacunkowo około 650 tys. ludności, tymczasem grupa Banu Jas mogła wzrosnąć najwyżej do kilkunastu tysięcy.
} 
odwołują się do koncepcji przekazania władzy przez Boga. Istnieją tu dwie formy odwoływania się do tej idei. Ród panujący często przypisuje sobie pochodzenie od proroka Mahometa. Taki rodowód mają dynastie rządzące w Maroku oraz w Jordanii. W Maroku od XVII w. rządzi dynastia Alawitów. Wywodzi ona swe pochodzenie od córki Mahometa Fatimy i jego zięcia Alego Ibn Abu Taliba. W tradycyjnym islamie nazywa się takie pochodzenie szarifatem. W Afryce Północnej rodów wywodzących się od Mahometa było niewiele. Uznawano więc, że szarifowie mają specjalne prawa do sprawowania władzy. Dwie dynastie marokańskie Sadyci w XVI w. i Alawici od XVII w. właśnie na bazie takiej genealogii budowały swój autorytet w plemiennym społeczeństwie. Podobna sytuacja dotyczy Haszymidów rządzących Jordanią, oni również powołują się na pochodzenie od proroka Mahometa poprzez jego córkę Fatimę i zięcia Alego ${ }^{14}$.

Oprócz tego genealogicznego argumentu tradycyjnych monarchii władca muzułmański może również powoływać się na fakt, że władza została mu powierzona przez Boga, by wykonał jakąś szczególną misję. Przywódca dżihadu, który rozszerza obszar islamu na ziemie niewiernych w sposób oczywisty jest kandydatem do założenia dynastii i jego sukces stanowi potwierdzenie boskiej nominacji. Podobna sytuacja występuje, gdy jakiś przywódca przeprowadza zmiany w islamie, powołując się na to, że realizuje nakaz Boga. W tych wypadkach ród panujący nie musi posiadać arystokratycznej genealogii. Dodowem na jego misję są sukcesy polityczne i militarne. Ten typ legitymizacji dotyczy dziś do pewnego stopnia Arabii Saudyjskiej. Ród Saudów w czasie budowy państwa przewodził fundamentalistycznemu ruchowi Wahhabitów i w swoim rozumieniu dokonywał odnowy świata islamu. Miał więc dane przez Boga prawo, by rządzić i niszczyć swych wrogów. Tego typu ideologia w pełni dotyczy natomiast Państwa Islamskiego i byłaby podstawą ustanowienia w nim monarchii o ile oczywiście ten twór państwowy przetrwa dłużej ${ }^{15}$

\section{POCZĄTKI JORDANII}

Ustrój monarchiczny doprowadził do ustabilizowania odrębnego państwa jordańskiego. Obiektywne warunki zdawały się jednak początkowo utrudniać ten proces. Trzeba przypomnieć, że Jordania nie posiada złóż ropy naftowej ani innych cennych surowców mineralnych natomiast użytki rolne to jedynie 4,5\% królestwa. Większość kraju zajmują pustynie. Ludność była początkowo bardzo nieliczna a potem szybko rosła w wyniku napływu uchodźców (obecnie około 5,6 mln). Obszar ten nie miał odrębnych tradycji państwowych. Dopiero Brytyjczycy wyodrębnili tereny Jordanii jako osobny emirat. Mimo tego ród Haszymidów zdołał utrwalić jej odrębność i swoją władzę ${ }^{16}$.

Dla zrozumienia wagi autorytetu rodu panującego dla stabilizacji państwa należy przypomnieć, że wśród bardzo wielu rodów przypisujących sobie szarifat, roszczenia Haszymidów są najlepiej udokumentowane. Ród ten rządził przez kilkaset lat w świętych miastach islamu Mekce i Medynie. Należał do najwyższej arabskiej arystokracji. W latach I wojny światowej naczelnik dynastii szarif Husajn poparł w 1916 r. Anglików i wystąpił przeciw rządowi tureckiemu. Po wojnie Husajn stał się królem Hidżazu. Jego synowie Fajsal i Abd Allah również otrzymali od Brytyjczyków trony. W 1921 r. Fajsal został

\footnotetext{
${ }^{14}$ A. Dziubiński, Historia Maroka, Wrocław 1983, s. 180 i 256.

${ }^{15}$ M. Al-Rasheed, Historia Arabii Saudyjskiej, Warszawa 2001, s. 43-47.

${ }^{16}$ Arabowie. Stownik encyklopedyczny, red. M.M. Dziekan, Warszawa 2001, s. 219.
} 
królem Iraku, a Abd Allah emirem Jordanii. W 1926 r. król Husajn stracił władzę w Hidżazie (w Mekce i Medynie), wygnał go przywódca Wahhabitów Abd al Aziz Ibn Saud. Ród utrzymał władzę tylko w Iraku i Jordanii. Jednak w 1958 r. zamach wojskowy w Bagdadzie doprowadził do wymordowania irackiej części dynastii. Tym samym z dawnego rodu Haszymidów z Mekki utrzymała się jedynie gałąź rządząca w Jordanii założona przez księcia Abd Allaha w 1921 roku $^{17}$.

W momencie, gdy obejmował on władzę na terenach przyszłej Jordanii nazywanej wtedy Transjordanią, były to ziemie pustynne $\mathrm{z}$ nielicznymi miasteczkami takimi jak Amman, który miał około 5 tys. ludności. Ogółem obszar ten miał być może 210 tys. ludności. Skromną administrację i oddziały żandarmerii stworzyli tam Brytyjczycy. Tym niemniej podlegały one formalnie Abd Allahowi. Dzięki autorytetowi szarifa udało się zminimalizować opór plemiennego społeczeństwa przeciw narzuceniu mu władzy państwowej. Plemiona Transjordanii tak rolnicze jak i koczownicze zaakceptowały autorytet emira, a od 1946 r. króla Abd Allaha. Stało się tak, gdyż stał za nim autorytet pochodzenia z wielkiego rodu Haszymidów. Oczywiście jednak liczyła się też siła (tę zapewniali Brytyjczycy) oraz możliwości płacenia dotacji szejkom plemion o co władca starał się na miarę swych możliwości ${ }^{18}$. Jedno było oczywiste. Jedynym argumentem na rzecz odrębności Transjordanii była władza Haszymidów w tym państwie. Okres protektoratu brytyjskiego trwał w latach 1921-1946.

\section{HASZYMIDZI WOBEC KRYZYSÓW}

Dla wykazania stabilizującej roli monarchii w kraju arabskim szczególnie przydatne będzie wskazanie na problemy i kryzysy jakie przechodziła Jordania. Sytuacja tego państwa była zaś szczególnie trudna. Przynajmniej trzykrotnie w latach 1948-1949, 1955-1957 i 1967-1970 monarchia była zagrożona a wraz z nią samo istnienie państwa jordańskiego. Jeszcze raz trzeba podkreślić, że poza tronem w Ammanie nie istniało inne uzasadnienie odrębnej państwowości Jordanii. Z punktu widzenia ideologii panarabskiej przyłączenie tych terenów do Syrii lub Iraku było czymś oczywistym.

W maju 1946 r. ogłoszono niepodległość Transjordanii a Abd Allaha proklamowano królem. Mimo to w wyniku podpisanego porozumienia z Wielką Brytanią, kraj był dalej uzależniony od Londynu. Armia królestwa była utrzymywana dzięki dotacjom brytyjskim i dowodzona przez brytyjskich oficerów na czele z Johnem Bagotem Glubbem jej szefem sztabu. W chwili, gdy wybuchła wojna w Palestynie w 1948 r. władze w Ammanie posłały tam swoje wojska. Król Abd Allah chciał zająć jedynie tereny przyznane przez ONZ stronie arabskiej. Uważał, że realizuje strategię uzgodnioną z Londynem, jednak niejasna polityka rządu brytyjskiego skomplikowała ten proces. Doszło do zaciętych walk sił jordańskich i armii izraelskiej. W rezultacie od maja do grudnia 1948 r. Amman opanował Zachodni Brzeg Jordanu i Wschodnią Jerozolimę. Siły izraelskie opanowały

\footnotetext{
${ }^{17}$ B. Wróblewski, Sojusz Wielkiej Brytanii z Haszymidzkim Królestwem Jordanii (1946-1958). Dylematy mocarstwa $w$ relacjach z zależnym partnerem, Rzeszów 2003, s. 30-31.

${ }^{18}$ B. Wróblewski, Jordania, Warszawa 2011, s. 41 i 47-48. Niepewne dane mówią o 150 tys. ludności osiadłej i 60 tys. wędrownych koczowników. Ta ostatnia wielkość jest niepewna i koczowników mogło być również około 100 tys.
} 
jednak wiele terenów arabskich i wypędziły z domów setki tysięcy ludzi (np. z miast Lydda i Ramla). Masy uchodźców zalały Amman i tereny na wschód od Jordanu ${ }^{19}$.

W stolicy protestowały przeciw królowi dziesiątki tysięcy palestyńskich uchodźców. Ludzi tych było więcej niż dotychczasowych stałych mieszkańców a miasto miało zaledwie kilkudziesięciu policjantów. Co więcej koszty armii i utrzymania uciekinierów przekroczyły wielokrotnie dochody państwa. Zdarzało się wtedy czasowe niepłacenie żołdu. Doszło również do sytuacji, że Abd Allah musiał osobiście uspokajać wrogą demonstrację pod pałacem. Tymczasem śmierć króla mogła zachwiać całym systemem państwowym. Z drugiej strony władca miał rzeczywiście autorytet wśród poddanych i potrafił rozładowywać napięcia swoimi osobistymi interwencjami. Ostatecznie państwo nazwane odtąd Jordanią przetrwało kryzys i powiększyło się o Zachodni Brzeg Jordanu. Stało się tak głównie dlatego, że armia złożona głównie z rekrutów z Transjordanii dochowała wierności monarsze. Armia jordańska była niewielką, ale dobrze wyszkoloną przez Brytyjczyków profesjonalną siłą. Żołnierze byli ochotnikami traktującymi służbę jako zawód. Dużą ich część stanowili Beduini, którzy uznawali naturalny autorytet szarifa Abd Allaha potomka Mahometa. Generalnie poddani z dawnej Transjordanii akceptowali rodową legitymizację władzy monarchy ${ }^{20}$.

W przypadku kolejnego kryzysu politycznego w Jordanii decydujący okazał się fakt, że po przyłączeniu Zachodniego Brzegu Jordanu 2/3 poddanych stanowili Palestyńczycy. Nowi poddani nie uznawali autorytetu Haszymidów a nawet podejrzewali dynastię o związki z Izraelem. 20 lipca 1951 r. młody Palestyńczyk zabił w Jerozolimie króla Abd Allaha. Przez krótki czas zastanawiano się wtedy czy nie połączyć kraju z Irakiem (też rządzonym przez Haszymidów). Ostatecznie królem został jego syn Talal, ale z powodu choroby psychicznej odsunięto go od władzy w 1953 r. Kolejnym monarchą został nastoletni wtedy wnuk Abd Allaha Husajn. Młodociany król miał początkowo słabą pozycję i dużą część władzy przejęła kamaryla dworska i politycy. Przeprowadzono demokratyzację ustroju ${ }^{21}$.

W społeczeństwie jordańskim wzrosła wtedy popularność lewicy panarabskiej. Olbrzymi wpływ uzyskał przywódca Egiptu Gamal Abdel Naser. W latach 1955-1956 dochodziło wciąż do masowych protestów ulicznych. Opozycja zwalczała związki z Londynem i ogólnie z Zachodem. Główną siłą przeciwników monarchii byli Palestyńczycy. Masy uchodźców były sfrustrowane i nie ufały rządowi. W tej sytuacji młody król Husajn zdecydował się na ryzykowną grę i czasowe poparcie sił antyzachodnich. W marcu 1956 r. z jego rozkazu usunięto brytyjskich oficerów dowodzących do tej pory armią, w tym dowódcę J. B. Glubba. 21 października 1956 r. odbyły się w Jordanii wybory, w których niewielką przewagę uzyskała lewica panarabska. Król zaakceptował ten wynik i powstał pronaserowski rząd Sulajmana an-Nabulsi. Wydawało się, że Jordania będzie stracona dla Zachodu ${ }^{22}$.

Przez kilka miesięcy rząd realizował proegipską politykę i w jej ramach zarabizowano korpus oficerski. Jednak król bynajmniej nie stracił poparcia w różnych grupach

\footnotetext{
19 J.B. Glubb, A Soldier with the Arabs, London 1957, s. 63-65 i 161-162; J. Lunt, The Arab Legion, London 1999, s. 117 i 123.

${ }^{20}$ A. Kirkbridge, From the Wings. Amman Memoirs 1947-1951, London 1976, s. 47-48.

${ }^{21} \mathrm{Ph}$. Robins, A History of Jordan, Cambridge 2004, s. 74 i 77. Król Husajn urodził się w 1935 r. Objął więc władzę, gdy osiągnął 18 lat.

22 Ibidem, s. 95-96.
} 
społecznych. 13 kwietnia 1957 r., gdy podobno oficerowie chcieli zorganizować przewrót, żołnierze Beduini zbuntowali się w imię obrony monarchii. Król osobiście uspakajał żołnierzy i przejął kontrolę nad armią. Te zamieszki o dość niejasnych przyczynach pozwoliły monarsze usunąć pronaserowskich dowódców i zastąpić ich ludźmi wiernymi dynastii. Armia w sumie okazała się wierna rodowi Haszymidów. To z kolei pozwoliło władcy równolegle zdymisjonować rząd an-Nabulsi. Co ważniejsze, armia dość brutalnie stłumiła do końca kwietnia demonstracje zwolenników premiera. Król Husajn wprowadził w 1957 r. de facto dyktaturę monarszą. Partie polityczne uległy likwidacji a parlament poddano ścisłej kontroli władz. Jednocześnie władca po pewnym czasie zniósł stan wyjątkowy. Jordania nie stała się typową dyktaturą wojskową, a król zachował możliwość liberalizowania systemu. Co najważniejsze mimo trwałej niechęci części Palestyńczyków autorytet szarifa powodował, że ludność generalnie nie kontestowała rządów króla ${ }^{23}$.

Kolejny kryzys państwa jordańskiego nastąpił w latach 1967-1970 i wynikał bezpośrednio $\mathrm{z}$ dążeń Husajna by odegrać istotną rolę $\mathrm{w}$ rozwiązywaniu problemu palestyńskiego. Brak pełnej integracji Palestyńczyków był istotną wada w strukturze królestwa. Po 1957 r. Jordania prowadziła proamerykańską politykę. Dotacje z USA pozwalały Ammanowi utrzymywać dużą armię bez dodatkowego obciążania społeczeństwa. Jednak w 1967 r. król podjął ryzykowaną decyzję. Związał się z Naserem i poparł OWP. Gdy 5 czerwca 1967 r. Izraelczycy zaatakowali Egipt Jordańczycy zgodnie z podpisanym sojuszem poparli Nasera. Atak izraelski objął więc także ich i w ciągu 6 dni wróg zdobył Wschodnią Jerozolimę i Zachodni Brzeg Jordanu a na wschodni brzeg rzeki przybyło ponad 200 tys. nowych uchodźców. Armia jordańska została w znacznej części rozbita. Po tej klęsce autorytet króla czasowo podupadł ${ }^{24}$.

W ciągu kolejnych trzech lat władze Jordanii zezwoliły na działanie na terenie państwa zbrojnych sił OWP. Oddziały te dzięki umiejętnej propagandzie zyskały znaczne poparcie wśród Palestyńczyków, zwłaszcza młodych. Ideologia wielu grup palestyńskich była skrajnie lewicowa. W 1970 r. zbrojne grupy palestyńskie przejęły kontrolę nad częścią Ammanu i Irbilu. Dwór mógł się obawiać, że OWP dąży do obalenia monarchii. Wielu przywódców tego ruchu mówiło o tym wprost. Z kolei zwycięstwo OWP najprawdopodobniej doprowadziłoby do okupacji izraelskiej i niszczycielskiej wojny. Ta perspektywa przestraszyła sporą część społeczeństwa. Dzięki zmianie nastroju ludności król przygotował kontratak i we wrześniu 1970 r. armia jordańska zaatakowała bazy Palestyńczyków. Żołnierze rekrutowani na wschód od Jordanu okazali pełną lojalność wobec monarchii. Do końca 1970 r. siły OWP w królestwie zostały rozbite a ich resztki za zgoda władz w 1971 r. przeniosły się do Syrii i Libanu. Tym samym uratowano monarchię i stabilność państwa, choć za cenę kilku tysięcy ofiar ${ }^{25}$.

W ciągu następnych kilkunastu lat król rządził autorytarnie i nie wybierano parlamentu. Monarcha nauczony doświadczeniem z 1967 r. unikał konfliktów z Izraelem i prowadził proamerykańska politykę. Strategia ta była niezbyt popularna w społeczeństwie, ale poza kręgiem uchodźców palestyńskich na ogół akceptowana.

\footnotetext{
${ }^{23}$ J. Lunt, The Arab..., s. 158 i 160-161; B. Wróblewski, Jordania..., s. 140-143.

${ }^{24} \mathrm{Ph}$. Robins, A History..., s. 121-124.

${ }^{25}$ B. Wróblewski, Jordania..., s. 170-175. Do akcji monarchę sprowokowały działania Ludowego Frontu Wyzwolenia Palestyny (LFWP). Grupa ta porwała do Jordanii trzy samoloty i bez zgody władz uwięziła w Ammanie kilkudziesięciu zachodnich zakładników. Bojownicy barykadowali też ulice stolicy, a nawet mieli ostrzelać orszak króla.
} 
Dzięki niej Jordania w latach 1971-1985 szybko rozwijała się gospodarczo i uniknęła klęsk w starciach z Izraelem lub walk wewnętrznych jak np. w Libanie. Zważywszy, jak słabe były początkowo atuty Jordanii oraz na fakt, że nie posiadała ona istotnych bogactw naturalnych to trzeba uznać, że państwo osiągnęło znaczny sukces.

\section{DEMOKRATYZACJA}

W wyniku utraty Zachodniego Brzegu Jordanu i rozbicia sił OWP monarchii przestała zagrażać zbrojna opozycja. Jednak kraj miał innego rodzaju problemy. W połowie lat osiemdziesiątych okazało się, że popadł w pułapkę zadłużenia a koniec zimnej wojny sprawił, że Zachód przestał być pobłażliwy w kwestiach ekonomicznych i żądał oszczędności. Poza tym autorytaryzm króla przestał odpowiadać części społeczeństwa. W kwietniu 1989 r. doszło do masowych zamieszek i to nie wśród Palestyńczyków, lecz wśród ludności rdzennej na południu kraju. Król kazał je stłumić, ale jednocześnie ogłosił zamiar powrotu do ustroju parlamentarnego. Wybory powszechne $\mathrm{z}$ dopuszczeniem różnych grup politycznych przeprowadzono 8 listopada 1989 r. Przyniosły one sukces Bractwu Muzułmańskiemu, choć organizacja nie zdobyła większości. W 1990 r. nastąpił atak Iraku na Kuwejt. Przeciw Bagdadowi wystąpiła koalicja na czele z USA. Równocześnie Irak uznał za swego wroga Izrael. Sprawiło to, że duża część ludności królestwa zdecydowanie popierała w tym konflikcie Bagdad. Gdy w 1991 r. rakiety irackie spadły na Tel Awiw w wielu miastach Jordanii wybuchł spontaniczny karnawał radości, głownie wśród Palestyńczyków. Dodatkowo król Husajn od kilku lat miał dobre relacje z Bagdadem. To wszystko postawiło monarchę przed poważnym problemem ${ }^{26}$.

Jordania nie przyłączyła się do antyirackiej koalicji. Króla oskarżano wprost, że jest sojusznikiem Saddama Husajna. Ta decyzja zapewniła mu duże poparcie społeczne w latach 1990-1991 mimo tego, że represje ekonomiczne ze strony Arabii Saudyjskiej spowodowały chwilowe załamanie gospodarcze. Król w 1991 r. powierzył rząd Bractwu Muzułmańskiemu co zabezpieczyło go przed opozycją tego kierunku. Rząd ten zdymisjonował już w listopadzie 1991 r., gdy sytuacja nad Zatoką Perską zasadniczo się wyjaśniła. Generalnie monarchia nie tylko przetrwała kryzys z lat 1990-1991, ale dokonała $\mathrm{w}$ tym okresie parlamentaryzacji ustroju. Wybory stały się trwałym elementem jego polityki. Co więcej dzięki zniesieniu ustaw wyjątkowych w Jordanii zaakceptowano zasadniczo wolność publikacji oraz ustrój wielopartyjny. Tak subtelna polityka łącząca demokratyzacje z poparciem dla Saddama Husajna oraz wolność prasy z rozwojem islamizmu była możliwa tylko dzięki autorytetowi monarchy, który był równocześnie szarifem ${ }^{27}$.

W następnych latach król Husajn powrócił do polityki prozachodniej. Ukoronowaniem tego procesu było podpisanie przez Jordanię traktatu pokojowego z Izraelem w $1993 \mathrm{r}$. Dla osiągnięcia tego rezultatu władze musiały tłumić liczne demonstracje popierane przez Bractwo Muzułmańskie. Król Husajn zmarł z 1999 r. po długim pełnym zmiennych decyzji panowaniu. Jego następcą został najstarszy syn Abd Allah II panujący do dziś. $\mathrm{W}$ ciągu tych lat w Jordanii odbywają się regularnie wybory parlamentarne, ale trzeba też stwierdzić, że władza wykonawcza znajduje się całkowicie w rękach króla. Co więcej, monarcha ma prawo rozwiązywać niewygodny parlament. Uprawnienie to było nieraz wykorzystane w praktyce. Monarcha może liczyć na dużą liczbę posłów wybieranych na

\footnotetext{
${ }^{26}$ Ibidem, s. 216-217.

${ }^{27}$ Ph. Robins, A History..., s. 173-174.
} 
południu kraju przez plemiona. Dawne konfederacje Beduinów wybierają swych przedstawicieli po konsultacji z dworem ${ }^{28}$.

\section{PODSUMOWANIE}

Przedstawiony powyżej rozwój królestwa jordańskiego pokazuje jak ważna była rola monarchii w kształtowaniu się państwa arabskiego i utrzymaniu jego stabilnego rozwoju w ciągu dziesięcioleci. Jeszcze raz trzeba zwrócić uwagę, że zastosowanie ustroju republikańskiego implikuje istnienie narodu typu europejskiego. Aby sprawne państwo parlamentarne mogło trwać musi istnieć idea nadrzędnej wspólnoty narodowej. To wyobrażenie musi być akceptowane przez ludność państwa w sposób rzeczywisty, a nie jedynie w deklaracjach intelektualistów. Aby tak było solidarność narodowa nie może być kontestowana przez równie silne poczucie przynależności plemiennej czy ponadpaństwową wspólnotę wyznaniową. Gdy tak się nie dzieje, ustanowienie rzeczywistej republiki staje się wątpliwe. Przykładem tego może być właśnie świat arabski. W większości państw tego regionu wprowadzono ustroje republikańskie. I wszędzie, poza Libanem, republiki te stały się dyktaturami wojskowymi, często o totalitarnych zapędach. W Libanie z kolei wybuchła 15-letnia wojna domowa. Taki rezultat był $\mathrm{w}$ gruncie rzeczy nieunikniony. Wobec braku w krajach arabskich rzeczywistych struktur nowoczesnego narodu parlamentaryzm mógł łatwo doprowadzić do rozpadu państwa. Ponieważ nie istniało poczucie narodowe w ramach krajów było więc rzeczą oczywistą, że posłowie będą reprezentować swoje plemienne lub religijne wspólnoty. Z kolei idea panarabska pozostała tylko wizją, która w żaden sposób nie wpływała na społeczności państwowe.

Republiki więc stały się opresyjnymi dyktaturami a obecnie wiele $\mathrm{z}$ nich na naszych oczach pogrążyło się w wojnach i anarchii politycznej. Natomiast monarchie arabskie zachowały tradycyjną ideę władzy sprawowanej z nadania Boga. Przykładem tego typu legalizmu jest właśnie Jordania. Podobna idea państwowa dotyczy też Maroka, tam dodatkowo tradycja państwowa jest o wiele starsza. W świecie arabskim po upadku dominacji Europy istnieje problem, którego wielu ludzi na Zachodzie nawet sobie nie uświadamia. Nie chodzi o to jak rządzić biednym, zacofanym społeczeństwem, które jednak wyobrażamy sobie na sposób zachodni. Problem jest inny. Chodzi o to, jak utrzymać jedność społeczeństw, które materialnie upodobniły się do zachodnich (np. w dziedzinie uzbrojenia), ale w swych strukturach społecznych pozostały bardzo różne.

W Jordanii mamy przykład wieloplemiennego społeczeństwa arabskiego, które w 1921 r. wtłoczono w sztuczne i przypadkowe granice w wyniku podziałów terytorialnych dokonywanych w Londynie. To samo dotyczyło zresztą Iraku, Syrii czy Libanu. Po prawie 100 latach trzeba uznać, że to monarchiczna Jordania wykazała największą stabilność.

\section{BIBLIOGRAFIA}

[1] Al-Rasheed M., Historia Arabii Saudyjskiej, Książka i Wiedza, Warszawa 2001.

\footnotetext{
${ }^{28}$ B. Milton-Edwards, P. Hinchcliffe, Jordan. A Hashemite Legacy, London-New York 2009.
} 
[2] Arabowie. Słownik encyklopedyczny, red. M.M. Dziekan, Wydawnictwo naukowe PWN, Warszawa 2001.

[3] Danecki J., Arabowie, Państwowy Instytut Wydawniczy, Warszawa 2001.

[4] Dziubiński A., Historia Maroka, Wydawnictwo Ossolineum, Wrocław 1983.

[5] George A., Jordan. Living in the Crossfire, Zed Books, London and New York 2005.

[6] Glubb J.B., A Soldier with the Arabs, London 1957.

[7] Hourani A., Historia Arabów, Wydawnictwo Marabut, Gdańsk 2002.

[8] Kirkbridge A., From the Wings. Amman Memoirs 1947-1951, London 1976.

[9] Król M., Historia myśli politycznej od Machiavellego po czasy współczesne, Wydawnictwo Arche, Gdańsk 2001.

[10]Lunt J., The Arab Legion, London 1999.

[11] Milton-Edwards B., Hinchcliffe P., Jordan. A Hashemite Legacy, LondonNew York 2009.

[12] Robins Ph., A History of Jordan, Cambridge 2004.

[13] Sylwestrzak A., Historia doktryn politycznych i prawnych, Wydawnictwo Prawnicze LexisNexis, Warszawa 2006.

[14] Vatikiotis P. J., Politics and Military in Jordan: A Study of the Arab Legion 1921-1957, Frank Cass, London 1967.

[15] Wróblewski B., Jordania, Wydawnictwo TRIO, Warszawa 2011.

[16] Wróblewski B., Sojusz Wielkiej Brytanii z Haszymidzkim Królestwem Jordanii (1946-1958). Dylematy mocarstwa $w$ relacjach $z$ zależnym partnerem, Wydawnictwo Uniwersytetu Rzeszowskiego, Rzeszów 2003.

[17]Zdanowski J., Historia Bliskiego Wschodu w XX wieku, Wydawnictwo Ossolineum, Wrocław 2010.

[18]Zdanowski J., Historia Wschodniej Arabii, Wydawnictwo Ossolineum, Wrocław 2004.

[19]Żebrowski J., Dzieje Syrii od czasów najdawniejszych do współczesności, Wydawnictwo Dialog, Warszawa 2006.

\section{STABILIZING ROLE OF THE MONARCHICAL SYSTEM IN THE ARAB WORLD} ON THE EXAMPLE OF THE HASHEMITE KINGDOM OF JORDAN

During last twenty years we have observed the process of political crisis escalation in the Arab world. In spite of the hopes of Western observers the year 2011 did not bring positive developments. In case of Syria, Iraq or Yemen we deal with outbreaks of many-year civil wars. It should be noted that disintegration of state structures concerns only the Arab republics, whereas countries with monarchical system of government maintain stability and are characterised by lesser repressiveness of state institutions towards citizens. The above text points to the role of such factor as legitimization of power. In republics there is no real element of national sovereignty. Legitimization of power is based mainly on having military power. In monarchies the traditional legitimization based on the idea of power given God was preserved. This concept turned out to be quite effective in segmentary Arab societies.

In the second part of the text these suppositions were proven on the basis of events from the history of the Hashemite Kingdom of Jordan. Attention was paid to how important was the role of the Hashemite's in creating this country. Numerous internal crises from years 1948-1949, 1956-1957, 1967-1970 and 1989-1991, which the country survived mainly because of the authority of the monarchy, were indicated. It also helped to avoid state anarchization as well as long-lasting oppressive dictatorship. In the environment without 
clear national identity (on the state level) monarchy turned out to be the main stabilizing element.

Keywords: monarchy, nation, Hashemites, Jordan, Husajn, Palestinians.

DOI:10.7862/rz.2017.hss.15

Przestano do redakcji: grudzień 2015 r.

Przyjęto do druku: marzec 2017 r. 